\title{
Familial Conflicts in the novels of Nayantara Shagal
}

\section{P.Lakshmilavanya ${ }^{1}$}

Assistant Professor of English, PVPSIT, Vijayawada,Andhra Pradesh,India

\section{Dr.B.Karuna ${ }^{2}$}

Associate Professor of English, Acharya Nagarjuna University,Andhra Pradesh,India

\begin{abstract}
:
Every man and woman is a member of family, which is the smallest unit of society. It gives some degree of mutual caring and sharing that brings knowledge, values and material benefits from generation to generation. As infants and small children we learn from our families the patterns of behavior that affects all our later relationships both with other individuals and with society as a whole. Families continue to be most basic and pervasive organization of society, bridging the gap between the individuals and the larger context of group activities such as jobs, communities, recreational activities and all the other social and economic organizations within which we interact. In twentieth century, Familial conflicts take much of the women novelists' attention as people face the problems, mainly emotional.
\end{abstract}

Keywords: organization, society, economic organizations, knowledge \& Familial conflicts.

\section{Introduction:}

This paper intends to study various kinds of familial conflicts in the life of an individual. Nayantara Sahgal's all novels revolved around this significant institution of society. With the changing times and values, the family, like the rest of society has undergone radical changes. In India the tradition has been of joint family which is nowadays changing into nuclear family. There have been many positive sides and advantages of living in a joint family, because it gives us a new ideology to experience variety of passions, thought and ideas of different members. The company of grandparents plants the seeds of finer sensibilities early in life. Right family teaches right behavior to the child to make him a good human being which is not to be found in nuclear families. But many a time it also leads to conflicts, tensions, dissatisfaction and expectations etc.

Family is also characterized by the relationships between individuals and these relationships change along with the experiences of the individuals. Family is a way of living together and meeting emotional needs through interactions. The living, the hating, the fun and the violence all provide an emotional environment within which the individual learn the skills that will show their interactions with others in the world around them. It will show their feelings of self-worth and their 
International Journal of Trends in English Language and Literature (IJTELL) An International Peer-Reviewed English Journal; Volume-2, Issue-3; 2021 $\underline{\text { www.ijtell.com }}$ Impact Factor: 5.144(SJIF)

ISSN: $2582-8487$

concern for others. In this social environment people interact with social change in order to deal with the emotional and physical needs of the family members. Different kinds of factors have made the family both the purveyor and the recipient of social change.

The Indian society can broadly be classified into three levels in terms of differences based on economic and political power: the upper class, the middle class and the working class. Though it is not always true that the three classes have very clear and defined boundaries, there is nevertheless a certain different identity that each of these classes projects in terms of lifestyles and attitudes. Nayantara Sahgal deals with the middle class urban life in major. Her protagonists are all product of it.

\section{Psychological complexities in Sahgal's novels:}

It is contended that the family and familial relationships in the novels of Nayantara Sahgal portray crucial transition of modern India, from a conventional and traditional social order to a liberal and urbanized socio-economic and cultural ethos. NayantaraSahgal's novels seeks to explore the psychological complexities in which the Indian middle class family gets radical changes brought about by industrialization, urbanization and the growing influences of western thought and attitudes. Her novels also reflect a radical shift in interpersonal relations and their impact upon the changes in the Indian family. There is nothing wrong if women want to ascertain their identity in world outside along with their home and family.
But male in majority take this as a threat to family and tradition. But the two worlds are closely connected because the family is the smallest unit of social life. Families always work through relationship, the base of the families is always marriage, but these families have their critics, rebels and dissidents like any other social group.

Sahgal's protagonists have their own analysis of its various bonds, ties and relationships. Families always plays an important role in her life, she tries her best to struggle for her family's survival. Her women are not radical feminists they do not perish; they do not rebel, but they survive through their self-realization and awareness which emerges from their own mind, which is the centre of struggle, conflict, intellectual amendment and revolution. Women have the power to asses and judge their condition and situation. Family is the most important thing but how much the family gives space and freedom to the individual is also a most question. Sometimes it reduces personal freedom and imposes aspirations and expectations which the individual take as burden in lack of capability to hold it. Rejection by a family can make the individual alienated and lead to feelings of loneliness and guilt.

\section{Familial conflicts in Sahgal's work:}

During the survey of her novels, there are various kinds of familial conflicts-the conflicts between father and daughter, brother and sister but the much focused conflict is between husband and wife which is the foundation and base of family from where many new relations start taking shape and develop. The 
International Journal of Trends in English Language and Literature (IJTELL) An International Peer-Reviewed English Journal; Volume-2, Issue-3; 2021

patriarchal system, under which the family functions, struggles with the characters' quest for freedom and individual space. In opposing the difficulties of selfhood, the protagonist is brought into conflict with his social environment. The novelists highlight the newly-awakened spirit of self-assertion, especially among characters who belong to the progressive middle class. The fictional concerns of the period are a projection of self-assertion and personal ambition, as against the earlier family-oriented efforts in all spheres of life. Conflicts are quite often caused by the patriarchal system under which families function.

In India, it is a part with a complex ideological grid in which gender, race, caste, class; religion, colonialism and nationalism all have a certain role. The patriarchal forces that shape the position of Indian men and women are constantly being shaped as political, social, cultural and ideological factors undergo modifications. "The bedrock is no longer made up of the old orthodoxies of religion, caste, and family; everywhere are fissures, explosions, shattering" (Indian Fiction Today 208). The assumptions of male domination are portrayed by the novelists leading to a consciousness of conflicting views. The social construct of femininity gives enormous psychological pressure on women through what Betty Friedan termed "the feminine mystique" - "the notion that the highest value and the only commitment for woman is the fulfillment of her own femininity" (The Feminine Mystique 13).

The ideal of femininity works principally through two myths - that of the obedience and passivity of a woman's temperament and the compulsive limitation of her role to the domestic boundaries, her purpose being marriage, reproduction and domestic labor. In India, this universal feminine mystique has been raised to the status of a religious belief. Novelists, especially women novelists, provide views into the female psyche and a wide range of female experience in their attempt to portray the new woman who refuses to play a mere puppet to her husband. This has led the writers of Indian fiction to redefine the man-woman equation with the inevitable confusions, trials, sufferings and conflicts of various kinds. Patriarchal forces are experienced in their most serious form within the domain of the family. Gender discrimination of male female experience lead to different expressions of power and domination, often hidden under show of love, in familial conflicts. The institution of marriage is the site of the most gradual form of sexual politics. It is within the private hell of marriages that we have significant and moving explorations in fiction of the repressive forces of patriarchal attitudes. It does not include possibilities of mutual love and concern, the woman's self-esteem and having her sense of identity and selfhood. In these fictional representations of reality, marriage becomes an institutionalized form of the domination of women by men within the most personal of relationships.

Indian society traditionally subordinates individual rights to group or social role expectations. As a result, woman's individual self is little recognized, and self-effacement is the only course left to her. The new awakening 
International Journal of Trends in English Language and Literature (IJTELL) An International Peer-Reviewed English Journal; Volume-2, Issue-3; 2021

among educated women, as depicted in the novels of the 1980s, has led to the emergence of a new woman who reforms her role and determines her integral part of family and society, thus "striking a true balance between extreme feminism and the conventional role of subjugation and selfdenial" (Feminism and Literature 220).

The confusion of women trapped between traditional values regarding womanhood and the power of individuality leads to an exposure of the emptiness of man-woman relationships based on predetermined patterns of gender inequality. "The impact of tradition and culture through long-surviving institutions and the ideologies woven into them cannot be ignored in the Indian context" (Patterns of Feminist Consciousness in Indian Women Writers 15). Through the depiction of women who refuse their submissive position women novelists significantly portrays the traditional idea of female virtue and marital morality, thus implicitly demanding a realignment of the parameters on which marriages function. As Nayantara Sahgal comments about the breaking of stereotypes by her women characters, In every novel, the heroine has moved one step further away from the stereotype of the virtuous woman into a new definition of virtue; traditional virtue lies in staying put, suffering.

\section{The New Woman does the opposite.}

Her virtue is courage, which is a willingness to risk the unknown and face the consequences (Passion for India 8485). Shashi Deshpande deals with such familial conflicts of Indian women with reference to marriage, which results in an identity crisis in an Indian woman's marital life. Her women characters conflict against Man-made double values of India's social system. Deshpande has emerged as a literary complement to Anita Desai. Her preoccupations are sociological whereas the latter's are psychological. She questions through her fiction the inferior status granted to women. Her heroines are rebellious and dynamic and in her fiction, the clash is between an assertive individual and outdated traditions. Deshpande, in her novels of the eighties, focuses attention on woman's quest for her own self-identity and its reality. In the process, the woman comes into problems with the family, which represents conservative traditions, emotional slavery and restrictions. These novels portray women as striving to become autonomous beings, free from the rules imposed by family, caste, culture and their own fears and guilt. Roots and Shadows reveals the struggle of Indu, who represents a set of modern women, educated and very much in contact with the society, dealing with critical problems like love, sex, marriage and individuality. In her attempt to assert her individuality, she is brought to face the problems with the family, with the male dominated world and society in general.

She cannot remain a puppet and she is unable to take decisions for herself and affirm her being. A middle class girl brought up in an orthodox Brahmin family, she rebels against Akka, the surrogate mother, whom she identifies as the mother figure since she had lost her mother at birth. She rebels against her world, her values, her wishes; and marries Jayant. 
International Journal of Trends in English Language and Literature (IJTELL) An International Peer-Reviewed English Journal; Volume-2, Issue-3; 2021 $\underline{\text { www.ijtell.com }}$ Impact Factor: 5.144(SJIF)

ISSN: $2582-8487$

Akka comments: "such marriages never work. Different castes, different languages.... it's all right for a while, they realize" (Roots and Shadows 74).

By rejecting Akka's orthodox values and rituals, she believes to gain freedom from the confining limits of family and society symbolized by her house. The parental home, a symbol of tradition and old-world values, is rejected in favor of autonomy. The woman's rejection of her family and all that it stands for is an indication of her individuality and her capacity to see her life independent of her past.

Anita Desai uses her fiction of the 1980 s to reflect a variety of human situations. In these situations, the family is a significant site of confrontations with multiple consequences. In Custody captures the competitions within the familial restrictions of the poet Nur. His two wives, Safiya and Imtiaz, have opposing temperaments. The first one is simple, loyal, hardworking and cooks, cleans, washes and manages the Nur household materially, whereas Imtiaz is selfish, fanciful and unpredictable. Apart from the unmatched nature of their characters and motives, there is conflict between Nur and Imtiaz. She is out to exploit Nur's opinion and even to outsmart the man and prove that she is a better poet than Nur himself. Though she is only a poet, she has a plan to excel Nur as a poet. Out of jealousy, she tries to stop the usual poetic sessions, the interview with Deven and the book which is planned to be written about the poet. She celebrates her birthday to win over Nur fans to her side by singing her verses, using all possible tricks. She removes Nur's secretary and is rightly accused by Safiya: "You've taken his name and his reputation and today even his admirers" (In Custody 90). She tries to persuade Nur that his poetry is outdated and he had better quit writing. Thus the conflict is found staying on two fronts within one single familial setup - frontal attacks between the two wives and clever, subtle conflicts between Nur and Imtiaz. It denotes the essentially complex nature of familial fights which increase in number and gravity owing to the growth of selfishness in the human psyche.

While portraying the family as a miniature of society Narayantara Sahgal shows how the social, economic, psychological, religious and other function and problems of the family are not dissimilar to those of society.

As the familial conflicts described in some novels of Indian writing in English some episodes in the novels of Nayantara Sahgal highlight the familial conflicts. In A Time to Be Happy Nayantara's prime consciousness is with self-expression within marriage. In This Time of Morning she widens her area of concern to the kind of liberty young women desire outside marriage. Nita and Rashmi are not willing to be passively submissive; instead they want to live their own lives. Nita wants a job of her own and resents the idea of an arranged marriage to perhaps one of the 'Putty-faced' men whose family regard her as a catch. Nita feels that the emotional content of such a marriage would be over shadowed by the material concerns, by the 'stocks and 
shares', 'money and clothes'. "And she 138 wonders what about her body and its desires....the body that pulsated for something with urgency she had never known" (This Time of Morning 14). Later when she is engaged to Vijay, he views her not as an individual with independent ideas and views but as a possession he is lucky to have acquired. To Nita this kind ofmarriage does not offer any prospect of fulfillment. She is withdrawn and unhappy in Vijay's presence.

Saroj, in Storm in Chandigarh is unable to find equality in her marriage. Inder, her husband is not only from a different cultural background but is a different kind of person altogether, Saroj who has been brought up in an atmosphere of freedom and trust has grown up to expect equality. She is confused by Inder's violent reaction to an affair she has had before her marriage. She tells him about it in all her innocence, but this is for him the beginning of a nagging suspicion. $\mathrm{He}$ considers it to be a serious moral lapse with which she stained their whole relationship. Inder believes himself to have been wronged. In an order that clearly demarcated the roles of men and women, unless that venerable order was breached, trampled and mocked. He was maddened by it. When it came over him, he sat looking at Saroj with a revulsion that had ancient, tribal, male roots (Storm in Chandigarh 36).

When Inder marries Saroj, she has the premarital relationship. It is a different thing that society, which lives by double moral standards, brands her as guilty. Saroj, however, is not really guilty. She is not dishonest and for her, it is a part of coincidence. For herself, she is warmly and wholly involved in her marriage but Inder is preoccupied to disturb by this one act, which he uses to degrade her and to destroy her sense of innocence. Inder's attitude is in keeping with the rest of his character. He has no time for good things, for emotional involvements or for tenderness; his whole nature is cruel and ruthless. While Saroj longs to penetrate his inflexibility, Inder persists in raking up the past and withdraws into his own self, leaving her outside, isolated and unhappy beating against, numbness like a bird against a window pane, trapped in a futile frenzy (97). Saroj's premarital relationship is only an outward symbol of the difference in their attitudes. Saroj wants to be recognized as an individual and wants to build up a relationship on that whereas Inder treats her merely as a wifepossession, a commodity. Women have been used as subordinate since ages. Women have been feeling it bitter because nobody wants to be used. Therefore 'marriage' has become an ugly word in her novels.

Inder feels ill at ease with her emotional needs. $\mathrm{He}$ is unable to understand why she cannot have a baby like other women. A wife, he feels, is one half of an enterprise who is meant take care of her husband's home and children and further her husband's career. Inder is unable to find any other kind of relationship with Saroj or for that matter even with Mara. Inder believes that even after a thousand years woman will still need a master. 
International Journal of Trends in English Language and Literature (IJTELL) An International Peer-Reviewed English Journal; Volume-2, Issue-3; 2021 $\underline{\text { www.ijtell.com }}$ Impact Factor: 5.144(SJIF)

ISSN: $2582-8487$

In The Day in Shadow Simrit's life with Som lacks continuity and warmth. She feels isolated within her skin and even the physical relationship is a false, not experienced on the level of emotional orgasm. It is an act with, a beginning and an end with nothing in between or even afterwards. Simrit feels so completely isolated from Som that the physical expert can no longer transport her unresisting to a comfortable place. Sex is a part of life not a separate relationship that can be isolated from the rest of life. Simrit finds her life disturbed and herself in the midst of a peculiar financial problem. The heavy tax payment is an attempt to enslave her in every way, and forces her divorce. It creates a confrontation with the age-old orthodox views regarding the status of women.

All her attempts to make others see the divorce settlement from her point view fail, as people do not see her as a person seeking freedom and fulfilment. The divorce settlement is a continuation of their marriage; it holds her down to the role of a victim and attempts to crush her desire to be free in a positive way. The first step she has to take is to face the situation and it is the courage of this stand that frees her from the bonds of the marriage as well as the divorce settlement. Out of this struggle to be free is born a new Simrit, a person who makes choices, takes decision and becomes aware of herself as a person. First the mind, then the body open up to new responses and life states itself in a new sense of fulfilment in her relationship with Raj, which is on equal terms. Simrit's divorce in The Day in Shadow does not suggest that marriage has failed as a social institution or that it has outlived its utility. On the other hand it clearly denotes the need for reciprocal relationship in marriage.

Nayantara's viewpoint proves her desire to place marriage in the proper social and emotional perspective. The relationship between man and woman within or outside marriage needs to be liberated from conventional approaches to it in order to become a satisfying and fulfilling one. Marriage is a system of slavery and escape way. It is not even a contract for it is wrong to approach it in that spirit. It is a partnership based on respect and consideration and requiring involvement from both. The prime concern of Nayantara is the need for a mature approach to a marriage, the need to nurture it with love and care and frankness. She wants communication, for men and women have their own boundaries. Though she is fully aware that men can be as unhappy as women when the relationship is not a satisfactory one, she asserts the point that ordinarily it is women who suffer more and is denied the right to self-expression.

There are other women who are victims of oppression like Uma in This Time of Morning and Leela Dubey in Storm in Chandigarh. They are victims of a patriarchal system, which has no scope for their individuality. But they fight against the system in their own way. Uma is married to a man much older than her and she refuses to conform to his expectations of her. Uma is young and light hearted and when she finds no means of self-expression within her marriage, she gives power to her wildness and displays 
her non-conformity to her husband's face. Arjun and Uma drift apart and are not living together physically and emotionally. It is many years later that Arjun realizes his own share in the failure of their marriage and feels that, "Though we give our enemies another chance-we never forgive those we love" (The Day in Shadow 167).

In a Situation in New Delhi, Madhu is portrayed as a victim of violence both physical and emotional. Before she is able to recover from the shock of having been raped, her family is engaged in seeking a husband for her and is more concerned with public opinion than with her individual feelings. Madhu who had been in terror of meeting her enemies again, is afraid of the unknown face and hands of the marriage to which they would deliver her. When her family refuses to listen to her she seeks shelter in death. She is able to break away from her engagement to Ravi Krishen. In fact, the strength of an individual character has nothing to do with conventionality or modernity. The women who have strong well- developed characters refuse to obey and they are able to overcome their lack of confidence.

Women like Devika and Lalita are not modern in the real sense of the term; they have merely adopted the façade of modernity without any corresponding change in their viewpoint on any of the significant issues in life. Uma Mitra and LeelaDubey likewise are not truly liberated; they merely conform to a different pattern of behavior. It is women like Saroj and Simrit who are unable to conform to any patterns and are possessed by immense desire to be honest with their own selves and those around them. The educational and social opportunities available to women in post independent India are in no way a guarantee in themselves of individual growth and liberation. The initiative in the final instance has to come from the person concerned. Nita moves towards selfawareness through uncertainty and confusion.

Sahgal portrays patriarchal system of humiliation and the essence of freedom. Nayantara believes that liberation should come from within. Her women characters in their search for self-expression and freedom do not turn sexual, instead they transform sex into a multidimensional relationships. Pre-marital relationships are not good or bad in themselves, there is much more to it than the plain moral law. When she leaves Inder, Saroj also leaves behind the sense of guilt, and Simrit is liberated from her feelings of guilt only when she abandons the practice of traditional morality. It appears that sexual relationships in her novels have become acts of non- conformity and are free from moral. Sex has brought $t$ merely happiness and this becomes an emotional fulfilment and a renewal. Nayantara seeks to describe the inflexible concepts of virtue and faithfulness through her women characters who have a kind of 'untouched innocence and integrity'.

Sahgal describes marriage as a 'life long suffering', if the other person is not sensitive enough. Marriage opens up a whole range of demands-demands of motherhood and sacrifice. She herself had 
a sickening feeling of the marriage, losing her freedom and identity. The heroines in the novels of Nayantara Sahgal prove that marriage, despite its much failure has in it seeds of starting life afresh. Simrit does show this in The Day in Shadow. Simrit and Som, Part Company and Simritdo live separately to see a new man in her life. Saroj in Storm in Chandigarh leaves her unreasonable and unfaithful husband. Devi in A Situation in New Delhi chooses to live her own way. For her love is the most important thing in life. In one of her interviews she says. I believe that there are fundamental differences of emphasis between. Indian feminism and Western feminism, and the issues are very different. Feminism in India is making a tremendous impact with less noise and drama than in the West. As far as my fiction is concerned, I feel Indian women are conditioned to stay put in the home, no matter what difficulties they face. They find it extremely, difficult to break family ties (The Quest 3).

Nayantara advocates for freedom and self-identity but she seems to be a conservative at heart. She is deeply involved in Indian tradition. She uses the Gandhian method of passive resistance. She says: In my usage 'passive' has an active meaning just as nonviolence has an active meaning. And my heroines such as Saroj and Simrit hold their patience until the time when living together with their husbands is impossible and revolt can no longer be avoided. When a critical moment comes they take the final step and just walk out, although the action entails walking into the unknown (The Quest 4). She is aware of the victimization of women. She has been aware of the fact that her own great grandmother was burn as Sati. But she is conscious of the fact that modern Indian women are strong and self-respecting. She believes that unless women are liberated, the nation cannot expect to be free. On sex she is a strong believer that it is a communion of souls and ultimately love is a mystical experience, sex has to be respected.

The women in NayantaraSahgal's novels are no longer caged animals but rather they have come out of the cage and enjoying the freedom. The women in her novels are intense and arrogant. They have come out of the custody, inside a closed room. RukminiBhaya Nair says, Women, conventionalized into their roles of wives, sisters and mothers have, as a result, remained trapped within a powerful crosscultural metaphor that violently divides the genders making us all, in one way or another, victims of Lawrence's PansySyndrome (Outlook 9).

Sahgal portrays her women characters with a lot of passion who are suffering due to sexual bias in a male dominated society. The women characters in most of the novels of Nayantara Sahgal feel that they are used as a piece of furniture. Marriage becomes a kind of solitary confinement of the human spirit. What forces the women characters to revolt against the conventional security of marriage is their yearning for a free communication of ideas, union of two human minds. The women characters in NayantaraSahgal's novels are educated and aware persons. They do not subscribe to the male chauvinistic theory of being 
exclusive private properties. In Women: Person or Possessions Nayantara Sahgal says: When I heard someone remark; 'We never allow our daughter to go out' or 'I can't do that, my husband would not like it, it sounded a very peculiar, alien jargon. As if I thought, women were property, not persons (Hindustan Times 34).

Sahgal strongly believes that woman cannot be taken as a 'sex object'. Her women characters represent the Indian feminism in the true sense of the term. To her, marriage without love and selfidentity is meaningless. Nayantara Sahgal is quite bold in her feminist approach. She differentiates the age-old notions of women being inferior. She is first novelist who is quite clear in her perception that man-woman relationship should be based on equality, understanding and love. Manwomen relationship without love is prostitution and nothing else. Nayantara Sahgal also destroys the age-old Hindu myth that husbands should be treated as God. In a letter she throws light on her women characters: I try to create the virtuous women- the modern Sita, if you like. My women 'are strivers and aspire, towards freedom, towards goodness, toward a compassionate world. Their virtue is quality of heart and mind and spirit, a kind of untouched innocence and integrity (Nayantara Sahgal 34).

\section{The New Woman:}

For Sahgal 'The New Woman' is determined to live in self-respect. She is no more under the four walls crying and waiting for the husband. She is no more Sati. According to her point of view the perception of morality is quite different on love ethics. Like Lawrence she believes that sex outside marriage may be a taboo but such relationship should be viewed with reference to a particular situation. It has to be contextual. Nayantara Sahgal attacks the century old institution of marriage as the important occasion in a woman's life without which she has no social identity and dignity. In this case, the plight of women as a colonized sex is pictured in Frantz Fanon's analysis of colonialism in 'The Wretched of the Earth'

According to her feminism does not mean giving up femininity but a passion for equality and fairness. Nayantara Sahgal, a courageous woman writer in Indian English, with bold approach and rebellious intent wants the Indian women to be free from her chains. Her novels have golden touch of feminine sprit. She has given her women a 'voice' with primal intense energy. A wife's sense of anger at her husband's adulterous affair finds expression in Bhushan's mother's anger in Mistaken Identity. She refuses to accept her husband's many affairs and his two subsequent marriages as but a reflection of the will of God. When her servant maid advises her to ignore the new alliances, since "a man goes from flower to flower" (29), Mother loses her temper. Not to be taken in by superstitions, she "tore the tapestry of a prancing Hanuman from the 151 wall and sent her water pitcher crashing" (29). She ultimately leaves her house to live with her communist Muslim lover Yusuf. Totally dominated by her husband who has taken two more wives, without sparing any feeling for her, she has been seething, angry but helpless at the way her husband treats her. 
Social taboos and traditions expect her to take his unfaithfulness in her stride, but she finally makes use of an opportunity to break loose from the confines of an unhappy marriage: Early one morning she left the family mansion. I saw her hesitate for a second at the entrance and hold her breath before she walked out to star in the most sensational scandal of the generation. Society has not forgiven this liaison between an illiterate Ranee and her communist lover, and the shameless public exhibition they make of it. But Mother and Yusuf are so love-mad; they haven't noticed their notoriety (193 - 194). Looking back on her early life some painful familial realities are revealed. Mother was betrothed at five, married at thirteen, and thereafter confined within the walls of her apartment. Nobody even took notice of her unwillingness to many. "The Ganges valley has other plans for its women" (156) - plans of marriage and motherhood. In order to get a son she goes on a number of pilgrimages, as per the order of the unwritten law relating to Indian family. Her yearning for life is not completely destroyed by the suppressing life she is forced to lead.

This explains her elopement to Leningrad with Yusuf. Bhushan recalls that Mother is apparently just a helpless observer when her father marries a second and later, a third wife. Though she is in no position to voice her disapproval, it does not mean that she would forgive him these marriages. Mother is seen behaving in a manner that is approved of by society. Yet, what Sahgal has tried to convey is that she is only going through the motions of playing the role of a ranee. In fact, her free spirit, her strong will submits to the demands of neither her husband nor the world. "She has always been a rebel. Her character has been one of restless questioning. She is a stronger person than her husband and refuses to accept his continued pursuit of pleasure and new ranees" (Nayantara Sahgal 263). Mother firmly believes that she alone has the right to be father's wife. She is not merely the mistress of the house with hardly any exposure to the outside world, but she displays a mind of her own. Her selfawareness does not necessarily come from any education in the conventional sense, yet she understands "the subtle difference between love and sex, which her obtuse husband does not" (263). Even when she goes on the two pilgrimages with father there is a touch of disobedience in her attitude. She does not beg the Lord for a son. In fact, it is more like a battle between the Mother and the Lord.

A woman who believes in herself, she fights her husband with regard to the man's new wives. The conflict between them is an indicator of the challenges thrown on Indian patriarchy as early as the 1920s, the decade in which the story is set. Mother does not like to be reminded of the pathetic experience of delivering a baby. Her maid says that the pain did not matter as she had been finally blessed with a son, a prime possession in the Indian social context, a token of familial heritage. "And smoke and ashes good it did me" (25). This is because she cannot forget the pain of labor, nor easily forgive the lasting destruction the baby has caused to her body. The compensatory nature of a son's 
International Journal of Trends in English Language and Literature (IJTELL) An International Peer-Reviewed English Journal; Volume-2, Issue-3; 2021 $\underline{\text { www.ijtell.com }}$ Impact Factor: 5.144(SJIF)

ISSN: $2582-8487$

birth seems to make up for all the sufferings preceding the same. The son as a prized possession is at the centre of the Indian family. But a girl child is considered nothing less than a curse.

In the same novel Bhushan asks his tutor about female infanticide and starts wondering "if the two girls Mother had had before me had been still after all or long buried in milky holes underground I bicycled over every day, frankly I did not trust father" (63-64). Sahgal's women see motherhood as something to be welcomed, an emotional and spiritual privilege that tine family and society enthusiastically confer on them. But the burdens of motherhood should be carried by the mother and the father has the patriarchal privileges because there is no male fraternity. The result is the frustration of the Indian mother in bringing up the children. This, at the sub-conscious level, gives birth to self-pity and helplessness and their expression in the form of familial conflicts.

While discussing the oppressions, sufferings and thirst for freedom on the part of Indian women within the limited familial conflicts, Sahgal says that compared with Western women, Indian women Experience an even greater struggle to my mind, because they are coming out of much deeper roots and they endure to the utmost. When at last they can't take any more they make no bones about leaving, about doing what has to be done. They do not stay to remain slaves at that point. They go (My Continuing Character in India: Nayantara Sahgal talks to Minoli Salgado 44). The new woman in Sahgal's novels directs her attack not against the institution of marriage, but against the inequality and injustice that is forced upon women by men using the institution of marriage. That Sahgal has perceptively noticed these familial conflicts is an index of her own faithfulness to the Indian reality. Indian culture and literature, religion and rituals have made secret plans to wrongful act to project marriage as the centre of a woman's life, without which she is prevented to have social identity and a reason for existence. This dangerous patriarchal idea has sunk deep into the psyche of the Indian woman. For centuries they have considered marriage ties as valuable and indissoluble; for centuries they have tolerated physical and mental brutalization, indifference and noncommunication. Education and enhanced career opportunities have opened out hitherto forbidden territory and barred gates, instilling the confidence to walk out on failed marriages.

Revoking patriarchal models of marital morality exclusively based on the wife's fidelity, Sahgal creates patterns for a "new marital morality based on mutual trust, consideration, generosity and absence of pretence, selfishness and selfcenteredness" (The Novels of Nayantara Sahgal ).

In Plans for Departure, Henry is so deeply in love with his wife Stella that he does not create an issue of her affair with Pryor. When Stella finally leaves him, he is not hurt though she has made a fool of him; he is even ready to adopt her illegitimate child. Anna's observes on Stella when she leaving Henry is an 
International Journal of Trends in English Language and Literature (IJTELL) An International Peer-Reviewed English Journal; Volume-2, Issue-3; 2021 $\underline{\text { www.ijtell.com }}$ Impact Factor: 5.144(SJIF)

ISSN: $2582-8487$

identity of her spirit of freedom: "Stella, instead of falling about in a faint, had the guts to pack up and leave and make a life somewhere else" (76). Henry's remark, on the other hand, is a comment on the way Stella used him: "They must have thought me fair, gullible game as they made their plans" (194).

Stella's and Lulu's conjugal conflicts in the same novel are revealed from their upbringing and accompanying attitudes. Products of the British Raj, they have been brought up believing in their superiority, and this conditioning colors their judgement throughout their married life. Stella's marriage to Brewster fails because she cannot recognize the loving and caring man that he is. To her, he is a sorrowful example of a man who goes about doing his job as a District magistrate without any feeling of self-importance. Lulu, the only daughter of a plantation owner, has grown up mistrusting the natives. She remains unconvinced of the possibility of unifying all the classes though this is clearly the aim of her preacher husband Marlowe. Brewster and Marlowe believe in equality and their outlook has the postcolonial mental makeup. On the contrary, Stella and Lulu has the colonial frame of mind.

Thus, the marital conflict in their cases may be traced to the contrast in their frames of mind, a great representative of many Indian families where different sets of attitudes displayed by spouses become a source of conflict. Incompatibility between spouses resulting in conjugal misunderstanding is reinforced by conflicting notions about love entertained by the partners. The incompatibility between Henry and Stella is a case in point. Stella finally cheats on Henry, and makes her plans for departure to start a new life with Robert Pryor, an imperialist, anti-India person. While Henry feels that "she didn't even know what 1 meant by love, and we certainly did not have it in common" (178), Stella when she knows Henry's death, comments thus to Pryor: "Poor Henry's dead too. His death made up for everything, didn't it darling?" (206).

This consistent portrayal of women in this light could be taken to mean that indifference to children could be a major reason in breaking the marital bonds. This view has been confirmed by Sahgal herself: "I have always felt that one's children are one's achievements as much as anything else one might do" (An Interview with Nayantara Sahgal 10).

On analysis, it is clear that their indifference to the child, absent or present, is indicative of their inadequacy as committed partners with all resultant conflicts. Personal relationships reflect both the changing social conditions and the conflicts of the individual mind. In an interview, Sahgal makes a clear comment explaining the interlinking of the public and private worlds in her fiction: Politics if by that we mean the use and misuse of power, invades our lives every day, both at the private domestic level and at the national level" (Passion for India 83). She thus reveals awareness that the family can be the site of power play and manipulation of a dangerously subtle nature.

\section{Conclusion:}

IJTELL | Blue Ava Ford Publications 
International Journal of Trends in English Language and Literature (IJTELL)

An International Peer-Reviewed English Journal; Volume-2, Issue-3; 2021

Sahgal establishes in the minds of the Indian women a sense of justice and shakes them off their long sleep. It is in this respect that Sahgal has contributed to the cause of feminism. In an article 'The Virtuous Woman', she seems to bring light to her aim as a writer. She writes: Through the re-writing women do, new Sita and Savitris will arise stripped of false sanctity and crowed with the human virtue of courage. Then at last we will know why they did what they did and how their lone, remote struggles can help our search for identity and emancipation (The Tribune 3).

References

Sahgal, Nayantara. A Time to be Happy.

New Delhi: Orient Paperbacks, 1964.

This Time of Morning. New Delhi: Orient Paperbacks, 1965.

A Situation in New Delhi. England: London Magazine Editors, 1977.

A Voice for Freedom. New Delhi: Hind Pocket Books, 1977.

Saghal, Nayantara and E.N.MangatRai. Relationship. New Delhi: Hind Pocket Books, 1994.

Autobiography Sahgal, Nayantara. Prison and the Chocolate Cake. London: Penguin Books, 2003.

From Fear Set Free. London: Penguin Books, 1978. Articles Sahgal ,Nayantara."This Time of Fulfilment," Femina.7 May (1976)15-16.

Asnani, Shyam M. The Novels of Nayantara Sahgal. New Delhi: Doaba House, 1987.

"Sahgal: The Novel as Political Biography," Recent

Commonwealth Literature.Eds.

R.K.Dhawan, P.V. Dhamija and A.K. Shrivastava. New Delhi: Prestige Publishers, 1989. 